\title{
Bone Marrow Stem Cell with Potential to Differentiate to Granulocytic and Monocytic Lineages
}

National Cancer Institute

\section{Source}

National Cancer Institute. Bone Marrow Stem Cell with Potential to Differentiate to

Granulocytic and Monocytic Lineages. NCI Thesaurus. Code C42766.

A primitive, undifferentiated blood cell which can undergo division and give rise to white blood cells in the neutrophil, eosinophil, basophil or monocyte lines. 